\title{
Thrombotic microangiopathy in juvenile dermatomyositis
}

\author{
A Frolenko $^{1 *}, \mathrm{~N} \mathrm{Bervina}^{2}, \mathrm{M} \mathrm{Kagan}^{2}$ \\ From 18th Pediatric Rheumatology European Society (PReS) Congress \\ Bruges, Belgium. 14-18 September 2011
}

\section{Objectives and study}

A 4- year-old boy was admitted to our hospital because of progressive proximal muscular weakness of 4 weeks duration, heliotrope rash, erythematous skin lesions in the trunk and limbs and febrile fever. The muscle enzymes were elevated: creatine kinase 7,056 IU/L (0170), aldolase $40.3 \mathrm{U} / \mathrm{L}(0-8)$, aspartate transaminase 601 $\mathrm{U} / \mathrm{L}$ (10-37), alanine transaminase $289 \mathrm{U} / \mathrm{L}$ (10-37). The laboratory test revealed a hemoglobin level of $86 \mathrm{~g} / \mathrm{dL}$, a platelet count of $100,000 / \mathrm{mm} 3$, an erythrocyte sedimentation rate of $30 \mathrm{~mm} / \mathrm{h}$. A peripheral blood smear revealed schistocytes (2\%). Urine analysis revealed large number of red blood cells and proteinuria 1.06 grams / liter. The level of total serum bilirubin was $37 \mu \mathrm{mol} / \mathrm{l}$ (normal up to $17 \mu \mathrm{mol} / \mathrm{l}$ ). Serum creatinine was 200 $\mu \mathrm{mol} / \mathrm{l}$. Direct and indirect Coombs' reaction was negative. Prothrombin and thrombin time and D-dimers were within normal limits.The serologic tests for the antinuclear antibody, antineutrophil cytoplasmic antibody, antibodies to DNA, cardiolipin antibodies, antibodies to $\beta 2$ glycoproteins were negative. Lupus anticoagulant was not detected. The electromyographic findings were consistent with the inflammatory myopathy. A renal biopsy contained 43 glomeruli and was evaluated by light and immunofluorescence microscopies. Diffuse fibrin-platelet thrombi were revealed in glomerular capillaries. Small arteries was narrowed by the swelling of the endothelium. The expression of the fibrin ++ . There were no immune deposits at any location.

\section{Methods}

The patient received three pulses of methylprednisolone $30 \mathrm{mg} / \mathrm{kg}$ daily, followed by oral prednisolone $60 \mathrm{mg} /$ day. Alternate-day plasmapheresis with fresh frozen plasma for 1 week and intravenous cyclophosphamide treatment $\left(750 \mathrm{mg} / \mathrm{m}^{2} /\right.$ month $)$ were started.

\section{Results}

The treatment resulted in slow improvement in his muscle weakness within 4 weeks along with markedly decreased muscle enzymes and normalization of renal function. Prednisolone was changed to $1 \mathrm{mg}$ /day of oral prednisolone, which was later decreased to $0.5 \mathrm{mg} /$ day followed by transition to long-term oral methotrexate $10 \mathrm{mg} / \mathrm{m} 2 /$ week (after 6 monthly pulses of cyclophosphamide).

\section{Conclusions}

The described clinical case demonstrates the varied nature of renal pathology at juvenile dermatomyositis. The kidney damage appeared to have been very severe. But under the well-timed and adequate therapy it underwent to a back development in a great degree.

\section{Author details}

'Department of Pediatric Rheumatology, Orenburg Regional Children's Hospital, Orenburg, Russia. ${ }^{2}$ Department of Pediatric Nephrology, Orenburg Regional Children's Hospital, Orenburg, Russia.

Published: 14 September 2011

doi:10.1186/1546-0096-9-S1-P49

Cite this article as: Frolenko et al:: Thrombotic microangiopathy in juvenile dermatomyositis. Pediatric Rheumatology 2011 9(Suppl 1):P49.

\footnotetext{
* Correspondence: annafr@mail.ru

'Department of Pediatric Rheumatology, Orenburg Regional Children's

Hospital, Orenburg, Russia

Full list of author information is available at the end of the article
}

(c) 2011 Frolenko et al; licensee BioMed Central Ltd. This is an open access article distributed under the terms of the Creative Commons Attribution License (http://creativecommons.org/licenses/by/2.0), which permits unrestricted use, distribution, and reproduction in any medium, provided the original work is properly cited. 